\title{
PENDIDIKAN POLITIK BERBASIS PEMIKIRAN ISLAM HUMANITER
}

\author{
Asma'ul Husna \\ Dosen FAI Unwahas Semarang
}

\begin{abstract}
Abstrak
Nilai-nilai moral yang dibawa al-Qur'an-menurut kalangan Islam humanis-secara substansialis telah memberikan panduan yang jelas bagaimana kehidupan manusia dibangun berdasarkan nilai-nilai keadilan dan kesamaan. Tujuan utama al-Qur'an tersebut adalah memberikan panduan berupa nilai-nilai dan perintah-perintah etik sosial kemasyarakatan dijunjung tinggi dan bersifat mengikat dalam kegiatan-kegiatan sosio-politik umat manusia. Karena itu, keharusan menegakan nilai-nilai etik-moral dari al-Qur'an menjadi keharusan bagi umat Islam, kapan dan dimanapun berada dengan cara yang positif-konstruktif. Pada titik inilah letak ruang gerak dari penafsiranpemahaman yang harus selalu dikontekstualisasikan dengan perkembangan kontemporer. Pendidikan politik berbasis ppemikiran Islam humaniter didasarkan pada nilai-nilai humanisme yang merupakan hakikat manusia. Materi pendidikan politik ini harus diupayakan untuk membangun kesadaran manusia secara mendasar.
\end{abstract}

Kata Kunci: pendidikan politik, Islam humaniter

\section{A. Pendahuluan}

Secara alamiah, manusia mempunyai fitrah sebagai makhluk politik (zoo politicon) yang tidak dapat dipisahkan dengan konteks sosialnya. Perbedaan yang ada dalam bentuk fisiologis manusia sebenarnya merupakan sunatullah dan kehendak Tuhan yang seharusnya dihadirkan sebagai potensi untuk menciptakan kehidupan sosial yang menjunjung tinggi nilai-nilai toleransi. Keragaman suku bangsa, ras, etnik, bahasa, budaya maupun dialek selayaknya dijadikan potensi dasar untuk membangun kehidupan bersama yang damai serta meneguhkan pola interaksi sosial dalam mewujudkan kehidupan bersama yang tenteram. Bukan malah sebaliknya, perbedaan yang ada di tengah kehidupan sosial yang kompleks dijadikan sebagai media disfungsional yang menyebabkan ketidakharmonisan sosial dan mengarah pada integrasi, konflik horisontal dan kekerasan sosial. Bikhu Parehk mengatakan bahwa keragaman merupakan sebuah keniscayaan 
kehidupan manusia. Oleh sebab itu keragaman haruslah di kelola sedemikian rupa untuk kebaikan kehidupan manusia itu sendiri. ${ }^{1}$

Di tengah kehidupan sosial yang penuh dengan keragaman, menjadi tantangan tersendiri dalam mengusung nilai politik yang harmoni. Terkadang dalam kehidupan sosial, nilai-nilai harmonis yang seharusnya menjadi dasaran dalam membangun pondasi kehidupan sosial yang damai malah berbalik menjadi ancaman perpecahan sosial karena hanya mengedepankan nilai-nilai anti humanis, anti kedamaian dan diskriminatif. Oleh karena itu, kapasitas manusia dengan kodrat kemanusiaannya sebagai makhluk humanis ternyata tidak mampu dijadikan dasaran kehidupan yang damai dan serasi.

Islam sebagai agama diyakini mempunyai nilai-nilai universal (rahmat al-li'alamin) dengan serangkaian nilai-nilai kemanusiaan, kedamaian dan keharmonisan di tengahtengah kehidupan sosial masyarakat. Islam dengan semangat religiusitasnya dituntut mampu untuk menumbuhkan kesadaran kepada masyarakat untuk hidup rukun dan berdampingan. ${ }^{2}$ Menurut Abdurrahman Wahid implementasi Islam sebagai rahmat bagi kehidupan (rahmatan li 'l-'älamīn) tanpa harus melihat latar belakang suku, ras, bahasa, gender dan geografis seseorang. Dalam pandangan ini Islam ditempatkan sebagai ruh (spirit) untuk membangun penghormatan terhadap hak asasi manusia (HAM). Menurut Abdurrahman Wahid Islam harus ditilik dari fungsinya sebagai pandangan hidup yang mementingkan kesejahteraan warga masyarakat, apapun bentuk masyarakat yang digunakan, masyarakat Islam atau bukan. ${ }^{3}$

Karena itu, universalisme Islam menampilkan kepedulian yang sangat besar kepada unsur-unsur utama dari kemanusiaan (al-insāniyyah), seperti keadilan, HAM, pluralisme dan demokrasi. ${ }^{4}$ Baginya, standar kemaslahatan yang harus ada dalam kehidupan manusia merupakan bentuk penghargaan terhadap nilai-nilai kemanusiaan. Prinsip tersebut terangkum dalam pola maqașid al-shari'ah, yang di dalamnya meliputi lima hak dasar manusia (al-kulliyat al-khams), yaitu perlindungan atas keyakinan atau agama (hifz al-din), perlindungan terhadap jiwa (hifz al-nafs), perlindungan terhadap kehidupan dan pemikiran (hifz 'l-'aql), jaminan atas kehormatan atau keturunan (hif̧ al-naș) serta

\footnotetext{
${ }^{1}$ Bhikhu Parekh. "National Culture and Multiculturalism" dalam Kenneth Thomson (ed.), Media And Cultural Regulation (London: Sage Publications. 1997)

2 M. Ainul Yaqin, Pendidikan Multikultural: Cross Cultural Understanding untuk Demokrasi dan Keadilan, (Jogjakarta, Pilar Media, 2005) hlm. 45

3 Abdurrahman Wahid, "Islam dan Masyarakat Bangsa", Jurnal Pesantren, Jakarta, Vol. VI, No. 3. 1989, hlm. 193-207

4 Abdurrahman Wahid, "Universalisme Islam dan Kosmopolitanisme Peradaban Islam", dalam Budhi Munawar Rahman (ed.), Kontekstualisasi Doktrin Islam dalam Sejarah, (Jakarta: Paramadina, 1994), hlm. 545552
} 
jaminan atas kepemilikan (hifz al-amwāl). ${ }^{5}$ Pada konteks ini, universalime pandangan hidup (welstanschauung) Islam terletak pada pandangan keadilan sosialnya. ${ }^{6}$

Disinilah dalam beragama seseorang harus memahami agamanya secara benar dan integral. Hal ini menjadi penting mengingat selama ini banyak orang yang beragama tetapi tidak memahami keberagamaannya (religiousity) secara benar. Fungsi agama, termasuk Islam harus mampu mengembalikan manusia kepada semangat religius (al-rūḥ al-tadayyun) sesuai dengan substansi ajaran Islam yang benar. Bentuk dari seseorang mampu memahami pola keberagamaannya yang benar adalah dilihat dari perilaku dalam kehidupannya sehari-hari yang diwarnai dengan ajaran agama. Semangat religiusitas tercermin dari tema-tema humanis yang di bawa Islam itu sendiri, seperti perdamaian, toleransi, keseimbangan dan keadilan. Islam dengan semangat keberagamaannya sangat menekankan bentuk egaliterian dalam membangun masyarakat yang beradab (al-madinah al-fadillah, civil society).

Oleh sebab itu dalam membangun kerukunan umat beragama di tengah masyarakat yang heterogen hendaknya dapat dilakukan dengan menumbuhkan semangat kebersamaan, pluralitas dan nasionalisme. Nilai pluralitas akan menghantarkan umat beragama pada pemahaman bahwa setiap agama mempunyai kesamaan dengan agama lain sekaligus kekhasan masing-masing sehingga berbeda satu dengan yang lain. Pada dasarnya semua agama (Islam, Kriten dan Yahudi) bermuara pada satu kesamaan esensial. Mengingat semangat pluralisme masing-masing agama akan menampilkan wujud yang plural, meskipun semua kebenaran bermuara kepada Tuhan. ${ }^{7}$

Dalam sistem sosial kemasyarakatan, pendidikan merupakan salah satu media yang mampu membantu mengembangkan segenap potensi yang dimiliki manusia. Seiring berjalannya waktu pelaksanaan pendidikan banyak mengalami persoalan pada hal peranan pendidikan sangat penting dalam memberikan pengaruh terhadap peningkatan kualitas kehidupan manusia. Azumardi Azra mendefinisikan pendidikan sebagai suatu proses pengubahan cara berfikir, penyuluhan dan latihan proses mendidik yang dengan ini nantinya bisa melahirkan individu, keluarga dan masyarakat yang saleh serta mampu menumbuhkan konsep konsep kemanusiaan yang baik diantara umat manusia. Oleh sebab itu pendidikan tidak berada dalam ruang yang hampa, melainkan ada dalam dan sesuai dengan konteks yang mengitarinya. ${ }^{8}$

\footnotetext{
${ }^{5}$ Ahmad Suaidy, Pesantren dan Demokratisasi, (Yogyakarta: LKiS, 2000), hlm. 100.

${ }^{6}$ Abdurrahman Wahid, "Universalisme Islam", hlm. 546

${ }^{7}$ Kautsar Azhari Noer, "Tuhan Yang Diciptakan dan Tuhan Yang Sebenarnya", Jurnal Paramadina, Vol I, Juli-Desember 1998 hlm. 128-135

${ }^{8}$ Azumardi Azra, Pendidikan Islam Tradisi dan Modernisasi Menuju Melinium Baru, (Jakarta: Logos, 2000),hlm.3
} 
Pendidikan politik dalam Islam harus bertujuan untuk menanamkan nilai-nilai demokratisasi, cara hidup yang lebih baik dan santun kepada masyarakat luas. Sehingga sikap-sikap seperti saling menghormati dan toleran terhadap keanekaragaman agama dan budaya dapat tercapai di tengah-tengah masyarakat plural. Beberapa nilai mendasar yang harus menjadi fokus perhatian pendidikan politik Islam ini antara lain dengan penanaman kesadaran kepada masyarakat akan keragaman (plurality), kesetaraan (equality), kemanusiaan (humanity), keadilan (justice) dan nilai-nilai demokrasi (democration values). ${ }^{9}$

Disinilah nilai-nilai demokratisasi akan melahirkan gagasan mengenai pendidikan politik yang dianggap mampu dijadikan solusi dalam mewujudkan pendidikan Islam yang humanis. Pendidikan yang tidak membenarkan adanya intimidasi, pengekangan dan pembatasan terhadap kreativitas guru dan murid. Hal ini dapat diwujudkan dengan upaya dalam menciptakan demokrasi pendidikan yang ditandai dengan adanya proses belajar-mengajar yang terbuka dan penuh dialog yang sehat dan bertanggungjawab. Suasana humanis dalam pendidikan akan mengantarkan tercapainya tujuan pendidikan Islam. Berangkat dari latarbelakang di atas makalah ini akan membahas mengenai pendidikan politik dalam berbasis pemikiran humanis.

\section{B. Islam dan Demokrasi}

Tarik menarik pemahaman mengenai relasi antara Islam dan demokrasi sampi saat ini masih terus terjadi. Komaruddin Hidayat, rektor UIN Syarif Hidayatullah Jakarta, mengemukakan bahwa secara umum terdapat tiga paradigma yang mendasari relasi Islam dan demokrasi ini yaitu; model paradoksal, model sekuler dan model teodemokratik. Pertama, model paradoksal atau model negatif, dimana antara Islam dan demokrasi tidak bisa dipertemukan bahkan cenderung berlawanan. Kedua, model sekular atau model netral, dimana hubungan antara Islam dan demokrasi besifat netral, karena urusan agama dan politik termasuk masalah demokrasi berjalan sendiri-sendiri. Ketiga, model teo-demokrasi atau model positif yang menyatakan bahwa Islam dan demokarsi mempunyai kesejajaran dan kesesuaian, sehingga agama dalam hal ini baik pada tataran teologis maupun sosiologis sangat mendukung proses demokratisasi. ${ }^{10}$

Lebih jauh klasifikasi model hubungan di atas dapat diturunkan untuk membaca relasi antara negara dan agama yang saat ini berkembang dikalangan umat Islam. Secara umum pandangan menganai relasi keduanya juga dibedakan menjadi tiga yaitu; pertama,

\footnotetext{
${ }^{9}$ Amin Abdullah, "Kesadaran Multikultural", dalam pengantar M. Ainul Yaqin, Pendidikan Multikultural: Cross Cultural Understanding untuk Demokrasi dan Keadilan, (Jogjakarta: Pilar Media, 2005) hlm. vxiii

10 Komaruddin Hidayat, "Tiga Model Hubungan Agama dan Demokrasi", dalam Elza Peldi Taher, Demokratisasi Politik Budaya dan Ekonomi, (Jakarta: Paramadina, 1994), hlm. 190-194
} 
paradigma integrasi (unified paradigm). Dalam paradigma ini agama adalah bagian dari negara dan negara adalah bagian dari agama, keduannya menjadi satu kesatuan yang tidak terpisahkan. Kedua, paradigma simbiotik (symbiothic paradigm), yaitu agama dan negara berhubungan secara simbiolis, dimana agama perlu negara untuk berkembang dan negara membutuhkan agama karena dapat berkembang dalam bimbingan moral dan etika. Ketiga, paradigma sekularisitik (secularistic paradigm), merupakan cara pandang yang melihat agama dan negara ada pemisahan (disparitas). Konsep al-dunyā al-akhïrah, al-dīn al-dawlah atau umūr al-dunyā umūr al-dīn di dikotomikan secara diametral. Dalam pandangan komunitas ini negara dan politik merupakan entitas yang didiami oleh banyak personel dengan beragam basis nilai, kesadaran, dan keyakinan, tidak hanya milik agama tertentu. ${ }^{11}$

Perbedaan yang terjadi dikalangan umat Islam tersebut menunjukan belum ada kata sepakat tentang demokrasi dikalangan umat Islam. Sebenarnya jika dirunut kebelakang dalam konteks politik, Islam pada dasarnya menitikberatkan pada tauhid dan kedaulatan Allah sebagai bentuk landasan dari sistem sosial dibawa oleh Nabi Muhammad SAW. Ajaran inilah yang merupakan titik pijak filsafat politik dalam Islam. Ajaran pokok Islam menekankan bahwa setiap manusia secara individual maupun kolektif mempunyai hak untuk memimpin dan mempertanggungjawabkan terhadap apa yang dipimpinnya. Setiap manusia memilki potensi yang sama dan sederajat untuk mencapai karir tertinggi dalam hidupnya.

Disinilah kalangan Islam humanis berpikir bahwa nilai-nilai moral yang dibawa alQur'an secara substansialis telah memberikan panduan yang jelas bagaimana kehidupan manusia dibangun berdasarkan nilai-nilai keadilan dan kesamaan. Tujuan utama alQur'an tersebut adalah memberikan panduan berupa nilai-nilai dan perintah-perintah etik sosial kemasyarakatan dijunjung tinggi dan bersifat mengikat dalam kegiatankegiatan sosio-politik umat manusia. Karena itu, keharusan menegakan nilai-nilai etikmoral dari al-Qur'an menjadi keharusan bagi umat Islam, kapan dan dimanapun berada dengan cara yang positif-konstruktif. Pada titik inilah letak ruang gerak dari penafsiranpemahaman yang harus selalu dikontekstualisasikan dengan perkembangan kontemporer. $^{12}$

Secara umum beberapa prinsip dalam al Qur'an yang sejalan dengan prinsip demokrasi di atas antara lain, pertama, prinsip kesetaraan adalah pandangan setiap orang memiliki kedudukan yang sama tanpa memandang perbedaan rasa, agama kedudukan sosial dan bahasa (QS. al-Hujurat: 13). Kedua, prinsip kebebasan yaitu adanya jaminan

11 John L. Eposito dan John O. Voll, Demokrasi di Negara-Negara Muslim: Problem dan Prospek, terj. Rahman Astuti (Bandung: Mizan, 1999), hlm. 27. Lihat juga dalam Marzuki Wahid (ed), Jejak Jejak Islam Politik, Synopsis Sejumlah Studi Islam Indonesia, (Jakarta: Dirjen Diktis Kemenag RI, 2004) hlm. 267

${ }^{12}$ Muhammad Taufik, "Pendidikan Demokrasi Pesantren", ibid., hlm. 33 
kepada setiap orang untuk menyampaikan pemikiran dan pendapat dengan cara yang baik, bertanggung jawab dan berahlaqul karimah (QS. al-Taubah; 105). Ketiga, prinsip musyawarah yaitu melibatkan pihak yang memiliki kepentingan untuk memutuskan urusan bersama (QS. Ali Imran: 159). Keempat, prinsip keadilan yaitu menempatkan suatu keputusan sesuai dengan hakikat kebenarannya (QS. al-Nisa'; 135). Kelima, prinsip keumatan yaitu kewajiban membela dan mepertahankan hak warga negara dari gangguan siapapun. Hak tersebut meliputi hak beragama, harta benda, kehormatan diri, keselamatan diri dan keturunan..$^{13}$

Dalam konteks Indonesia prinsip-prinsip dasar tersebut merupakan landasan utama dalam membangun demokrasi yang sesungguhnya, sebab demokrasi jika hanya dipahami sebagai rutinitas penyelenggaraan kegiatan politik semata tidak akan memberikan konstribusi apapun bagi masyarakat. Demokrasi hendaknya dipahami sebagai sebuah instrumen penjaminan hak-hak rakyat, pengembangan demokrasi haruslah dipahami secara mendasar, dan tidak hanya dipermukaan saja. Kegagalan berdemokrasi banyak disebabkan karena demokrasi dilaksanakan pada ranah prosedural serta belum menyentuh substansi demokrasi yang sesungguhnya seperti; kesetaraan, kebebasan, penghargaan nilai-nilai lokal, pluralisme dan perdamaian.14 Demokrasi pada ranah permukaan ini secara normatif telah dilaksanakan di Indonesia seperti pelaksanaan pemilu, pelaksanaan pilkada dan kegiatan politik lainnya, namun pada ranah yang lebih substansi yang berupa pemampuan atau pemberdayaan masyarakat belum banyak tersentuh. Disinilah pentingnya pemampuan masyarakat sebagai upaya peningkatan kualitas demokrasi.

Dengan bersendikan nilai etik tersebut kalangan Islam humanis berusaha membangun demokrasi yang sesungguhnya. Melalui demokrasi yang lebih substantif ini diharapkan akan terbangun suatu masyarakat yang komunikatif, yang dicirikan dengan adanya konsensus, kesetaraan, saling memahami, dan kesediaan untuk berdialog. Dalam istilah yang gunakan Habermas hal ini disebut sebagai tindakan komunikatif. Tindakan ini berpusat pada sincerity (antara intensi yang dimaksud dengan yang diucapkan terdapat kesatuan), exactness (ketepatan rumusan tidakan dalam dialog), truthness (kebenaran sebagai acuan dalam komunikasi) dan comprehenshipness (keseluruhan). Dengan demikian komunikasi yang dibangun tidak hanya bersumber pada keinginan suatu kelompok untuk dipahami oleh yang lain, namun juga ada kesediaan dari kelompok tersebut memahami kelompok yang lain. Artinya dalam masyarakat akan ada kesusaian

${ }^{13}$ Lihat KH. Abdurrahman Chudlori, Dasar Politik Kyai dan PKNU, (Jakarta: DPP PKNU, 2007), hlm. 25

${ }^{14}$ Lihat Mahfud MD, Hukum dan Pilar-pilar Demokrasi, (Yogyakarta: Gema Media, 1999), hlm. 37 
antara relasi-relasi sosial yang terbangun. Hal ini dalam rangka mencari kesepahaman bersama (mutual understanding). ${ }^{15}$

Pemikiran ini sejalan dengan peandangan Abdurrahman Wahid yang mengemukakan pentingnya pereduksian ajaran agama pada tahap seminimal mungkin sehingga mampu dijadikan etika sosial bersama. Dalam hal ini Abdurrahman Wahid mencoba menetralisir ketegangan hubungan Islam dan negara dengan memberikan dua tawaran alternatif, yaitu menempatkan Islam sebagai etika sosial dan pribumisasi Islam. Baginya agama tidak boleh dikaitkan dengan urusan negara, agama diposisikannya sebagai sesuatu yang individual (bersifat pribadi), moral dan semata-mata ritual. ${ }^{16}$

Oleh sebab itu agama hanya berperan sebagai suatu nilai etika (moral, akhlak), bukan sebagai aturan praktis (syariat Islam), karena itu ia memperjuangkan tegaknya (nilai) Islam yang tidak memberlakukan hukum Islam dalam negara. Disinilah Abdurahman Wahid menolak konsep negara Islam, karena sejak lama ia mengemukakan bahwa Islam tidak berfungsi ideologi di kalangan mayoritas umat Islam karena wilayah kehidupan suatu agama memiliki otonominya sendiri. Menurutnya Islam secara historis belum merumuskan tentang negara Islam, sehingga tuntutan harus adanya negara Islam, rapuh sekali. Unsur yang membentuk masyarakat bukanlah agama, melainkan ikatan kebersamaan atau kebangsaan, dan agama menjadi bagian dalam membentuk dasar dari kenegaraan tersebut. ${ }^{17}$

Dalam masayarakat yang demikian maka segala persoalan akan di dialogkan dan di negosiasikan secara egaliter. Dengan pengedepanan demokrasi yang substantif berarti berusaha mengembalikan kekuasaan dalam negara kepada jati dirinya yang genuin,

${ }^{15}$ Jugen Habermas termasuk filosof paling terkemuka dalam 30 tahun terakhir. Ia lahir pada tanggal 18 Juni 1929 di kota Dusseldorf, Jerman. Ia belajar filsafat, sejarah, psikologi dan sastra Jerman di Gottingen, Zurich dan Bonn di mana ia memperoleh gelar doktor dalam fifsafat dengan disertasi tentang Schlling. Pada tahun 1956, ia diangkat sebagai asisten pada Institut fur Sozialforschung Universitas Frankfurt dibawah pimpinan Max Horkheimer. Pada tahun 1962, ia menjadi professor di Heidelberg dan dua tahun kemudian menggatikan Adormo sebagai professor untuk filsafat dan sosiologi di Frankfurt Karena bentrok terus dengan para mahasiswa kiri, Habermas meninggalkan dunia universitas pada tahun 1971 dan bersama CarlFriedrich Von Weizsacker menjadi direktur Lembaga Max-Plank untuk penelitian syarat-syarat Hidup Dunia Ilmiah- Teknis yang baru didirikan di Starnberg. Baru tahun 1982 ia kembali ke Universitas Frankfurt. Tahun 1994, ia dipensiun dan sekarang tinggal di Starnberg. Lihat Franz Magnis Suseno, 12 Tokoh Etika Abad ke-20, (Yogyakarta, Kanisius, 2000), hlm. 215 125

${ }^{16}$ Lihat Khamami Zada (ed.), Neraca Gus Dur di Panggung Kekuasaan, (Jakarta: Lakspedam, 2002), hlm.

${ }^{17}$ Dalam membangun argumentasinya tentang relasi Islam dan negara, Abdurrahman Wahid paling tidak menggunakan dua argumentasi, yaitu: pertama, argumentasi normatif-teologis, yang dimulai dengan menyebut bahwa istilah dawlah Islamiyyah (Islamic state) tidak pernah eksplisit disebutkan dalam al-Qur'an. Kedua, argumentasi historis, berkaitan dengan fakta dalam sejarah tidak ada mekanisme baku bagaiamana mekanisme suksesi dalam Islam. Abdurrahman Wahid, "Islam Punyakah Konsep Kenegaraan?", Tempo, 26 Maret 1982; Lihat juga tulisan yang dihimpun dalam buku Tuhan Tak Perlu Dibela (Yogyakarta: LKiS, 1999), hlm. 17 
demokrasi bukanlah politik kekuasaan sekelompok orang saja, akan tetapi menjadi jejaring kekuasaan dari seluruh elemen masyarakat termasuk umat Islam. Menurut Focoult kekuasaan harus dipahami dan dilabuhkan dalam realitas. Bagi pemikir Islam humanis seperti Nurcholis Madjid dan Abdurrahman Wahid, persoalan di atas dalam rangka menghindari adanya proses-proses pendangkalan agama yang disebabkan oleh beberapa hal, antara lain: pertama, pengaruh politik Islam yang menempatkan Islam sebagai ideologi, komuditas politik, baik yang menindas maupun yang tertindas. Kedua, faktor proses pendidikan dan dakwah yang cenderung bersifat memusuhi, mencurigai dan tidak mau mengerti agama lain.18

Disinilah pada dasarnya demokrasi bukan hanya menyangkut sistem politik pada tingkat negara, dan lebih dari itu bahwa demokrasi juga mencakup kehidupan keseharian masyarakat. Proses demokrasi harus tercermin dalam interaksi antar kelompok dan golongan dalam masyarakat, karena pola kehidupan keluarga, bahkan hubungan antar individu harus didasarkan pada sistem demokrasi. Dalam pengertian lain bahwa demokratisasi harus dimulai dari ruang terkecil dalam interaksi masyarakat, baik pada tataran individu, struktur relasi kekuasaan juga menentukan esensi dan kualitas demokrasi level di atasnya yaitu masyarakat dan negara. ${ }^{19}$ Proses demokrasi akan berlangsung lebih baik jika setiap individu memiliki pengetahuan yang memadai tentang nilai-nilai demokrasi. Kedua tataran inilah yang menentukan karakteristik demokrasi modern yang oleh Huntington disebut sebagai demokrasi yang mendasarkan pada negara-kebangsaan.

\section{Pendidikan Politik Berbasis Pemikiran Islam Humanis}

\section{Humanisme sebagai Dasar Pendidikan Politik}

Humanisme merupakan sebuah proses pembebasan manusiawi atau yang dikenal dengan transformasi struktural non-revolusioner. Adanya kecenderungan ideologisasi dari gerakan humanisme inilah yang harus dihindari pada Islam, karena semua itu hanya menciptakan ruang ekslusivisme dan ekstrimisme, meskipun berangkat dari paradigma pembebasan. Menurut Islam humanis bahwa setiap agama termasuk Islam menyimpan kekuatan pembebasan, namun dunia juga mempunyai mekanisme perubahan tersendiri sehingga bahaya ketika agama diturunkan pada teknik dan penentu pembebasan, karena

18 Abdurrahman Wahid, "Dialog Agama dan Masalah Pendangkalan Agama", dan "Kebebasan Agama dan Hegemoni Negara", dalam Komaruddin Hidayat dan Ahmad Gaus AF (ed.), Passing Over Melintasi Batas Agama (Jakarta: Paramadina, 1998), hlm. 51-52

${ }^{19}$ Abdurrahman Wahid, Mengurai Hubungan Negara dan Demokrasi, (Jakarta: Grasindo, 1999), hlm. 30 
agama bisa menjelma menjadi institusi kekuasaan yang menindas atas nama otoritas agama. ${ }^{20}$

Nilai humanisme yang menjadi dasar pendidikan politik dalam Islam mensyaratkan setiap komunitas agama memiliki kesetaraan. Kesetaraan tersebut meliputi: pertama, negara akan menegakkan kesetaraan seluruh komunitas beragama dihadapan hukum, tidak berpihak atau mengistemawakan satu yang manapun, tetapi konsultasi dan bekerja sama antara komunitas beragama berkaitan dengan kepentingan bersama. Kedua, komunitas beragama secara sendiri-sendiri atau bersama-sama meminta negara untuk berdialog dengan mereka mengenai masalah yang penting. Ketiga, negara akan menjaga kerahasiaan profesional orang-orang yang menjalankan kepemimpinan dalam komunitas beragama menyangkut informasi uang diperoleh dalam tugas keamanan mereka. $\mathrm{Ke}$ empat, tidak akan ada diskriminasi berdasarkan afiliasi keagamaan dalam praktik pemerintahan. ${ }^{21}$

Komunitas keagamaan berhak melakukan mempromosikan nilai-nilai spiritual ataupun moral, mendamaikan, merekonstruksi sesuai dengan ajaran agama mereka sendiri. Selain itu, penganut agama diharapkan tetap kritis terhadap dirinya sendiri dan berupaya menghilangkan diskriminasi berdasarkan gender, ras, bahasa, ataupun status sosial dalam masyarakat, serta menghindari konspirasi atau pelanggaran kepentingan publik dan hak hukum orang lain. ${ }^{22}$

Berangkat dari pandangan di atas, dapat dipahami bahwa pendidikan politik sebagai aspek paling penting bagi upaya menumbuhkan sikap dan perilaku demokratis maka perlu didasari prinsip humanisme. Dalam hal ini tujuannya adalah bagaimana mendidik siswa atau peserta didik dalam hal ini adalah masyarakat agar dapat berfikir kritis. Proses ini dilakukan untuk membangun adanya kebebasan dalam pendidikan yang akan terwujud dalam demokratisasi pendidikan di masyarakat. Dalam lingkup kecil di sekolah misalnya upaya dalam menciptakan demokrasi pendidikan ditandai dengan adanya proses belajar-mengajar yang terbuka dan penuh dialog yang sehat dan bertanggungjawab antara pendidik dan peserta didik.

Pendidikan politik yang didasarkan pada aspek humanisme ini mensyaratkan adanya pemahaman menganai hakikat manusia. Salah seoarang tokoh dalam Islam yang konsen dengan pemahaman ini adalah al-Mawardi. Al-Mawardi menjelaskan bahwa Tuhan menciptakan manusia dengan segala ketentuan-Nya. Tuhan menciptakan manusia dengan sifat kelembutan dan keindahan-Nya menjadi makhluk yang konsumtif dan

${ }^{20}$ Abdurrahman Wahid, "Kata Pengantar", dalam Einar Martahan Sitompul, Nahdaltul Ulama dan Pancasila, (Jakarta: Sinar Harapan, 1989), hlm. 9

21 Farid Esaac, Al-Qur'an Liberation and Pluraisme: Membebaskan Yang Tertindas, (Bandung: Mizan, 2000), hlm. 334

${ }^{22}$ Farid Esaac, Al-Qur'an Liberation and Pluraisme, hlm. 335 
memiliki berbagai kelemahan. Tujuannya adalah agar manusia menyadari atas ketidakerdayaannya hidup secara individual dengan bekal kemampuan yang terbatas. Keterbatasan, kelemahan, dan sifat serba kekurangan yang ada pada diri manusia, diharapkan dapat menyadarkan dirinya, bahwa dibalik itu semua Tuhan lah yang Maha Sempurna. Pemberian rezki kepada manusia sesuai dengan amal perbuatannya. ${ }^{23}$

Untuk mewujudkan pendidikan yang demokratis dan humanis sebagaimana hal di atas maka kerangka acuan pemikiran dan pengembangan sistem pendidikan politik harus mengedepankan prinsip-prinsip yang mampu mendukung gagasan tersebut sperti kesetaraan, kejujuran dan keadilan. Secara umum Faisal Jalal mengatakan prisnisp tersebut antara lain; pertama, pendidikan harus membangun prinsip kesetaraan (equality). Kedua, pendidikan merupakan wahana pemberdayaan masyarakat (society empowerment). Ketiga, prinsip pemberdayaan masyarakat harus digunakan untuk memaksimalkan peran dan fungsi pendidikan dalam pengembangan potensi manusia. Keempat, prinsip kemandirian. Kelima, prinsip toleransi (tasamuh) dan konsesus di tengah masyarakat yang plural. Keenam, prinsip perencanaan (planning). Ketujuh, prinsip rekonstruksionisme. Kedelapan, prinsip pendidikan yang diarahkan pada peserta didik sebagai subjek (paedagogic). Kesembilan, prinsip pendidikan multikultural. Kesepuluh, prinsip global. ${ }^{24}$

Pendidikan politik dituntut harus dapat mengembangkan afektif dan psikomotorik manusia agar mampu menjawab tantangan internal dan eksternal dalam mewujudkan proses sosial yang demokratis, berkualitas, dan kritis. Karena itu, pendidikan politik harus dikembangkan berdasar pada paradigma yang berorientasi pada pembangunan, pembaharuan, pengembangan kreativitas, intelektualitas, keterampilan, kecakapan penalaran yang dilandasi dengan keluhuran moral dan kepribadian sehingga akan melahirkan peserta didik yang terus belajar (long life education), mandiri, disiplin, terbuka, demokratis, inovatif, dan mampu menyelsaikan persoalan kehidupan. ${ }^{25}$

Oleh sebab itu perlu adanya rekonstruksi pendidikan politik untuk memperteguh dimensi kontrak sosial-keagamaan dalam pendidikan agama. ${ }^{26}$ Maka pendidikan politik harus diorientasikan kepada; pertama, humanisasi pendidikan berakar dari keunikan personalitas anak manusia. Kebijakan yang sentralisitk, yang mengabaikan personalitas kemanusiaan dan bentuk penyeragaman, serta metode pendidikan yang tidak memberikan peluang terhadap tumbuh dan berkembangnya potensi manusia merupakan akar

\footnotetext{
${ }^{23}$ Al-Mawardi, Adab al-Dunyā wa al-Dīn, hlm 132

${ }^{24}$ Lihat Fasli Jalal, Reformasi Pendidikan dalam Konteks Otonomi Daerah, (Yogyakarta: Aditia, 2001), hlm. 17

${ }^{25}$ Faisal Ismail, Paradigma Kebudayaan Islam Studi Kritis dan Refleksi Historis, (Yogyakarta: Tiara Illahi Press, 1998), hlm. 98

${ }^{26}$ Amin Abdullah, Studi Agama: Normativitas dan Historisitas, (Yogyakarta: Pustaka Pelajar, 1999), hlm.
} 
dari dehumanisasi. Kedua, humanisasi pendidikan dapat dijalankan dengan bentuk demokratisasi pendidikan. Demokratisasi pendidikan menjadi syarat mutlak bagi terbentuknya suasana dialogis dan humanis. Di dalam proses sosial di masyarakat hendaknya dijalankan dengan penuh keterbukaan, peserta mendapat kesempatan penuh untuk mengekspresikan dirinya. Begitu juga hubungan antara guru dan siswa. Hubungan itu dibangun atas kemitraan, bukan sebagai atasan dan bawahan, melainkan merupakan partner dalam mengantarkan proses belajar mengajar untuk menemukan kesadaran hidup.

\section{Materi Pendidikan Politik}

Gerakan demokratisasi yang dibangun oleh pemikir Islam merupakan upaya untuk membangun dasar-dasar persamaan, kebebasan, keadilan, keterbukaan dan anti diskriminasi. Oleh sebab itu sistem pendidikan politik harus berorientasi pada penanaman kesadaran kritis agar mampu membangun frame work yang memungkinkan untuk memahami berbagai persoalan hidup yang ada. Materi pendidikan menjadi hal yang mendasar dalam hal ini, karena materi pendidikan politik harus mengarah pada penguatan atas pluralis, menekankan penghayatan hidup serta refleksi untuk menjadi manusia yang utuh dan mampu menghormati hak-hak orang lain.

Proses ini didasarkan pada pemahaman, pertama, pendidikan politik hendaknya menempatkan masyarakat sebagai pelaku aktif bukan sasaran pasif. Kedua, adanya penguatan potensi lokal baik yang berupa karakteristik, tokoh, pranata, dan jejaring. Ketiga, adanya peran aktif masyarakat mulai dari perencanaan, pengorganisasian, pelaksanaan, pemantauan, refleksi, dan evaluasi. Keempat, teradinya peningkatan kesadaran, dari kesadaran semu dan kesadaran naif ke kesadaran kritis. Kelima, adanya kesinambungan program yang ada dimasyarakat.

Pendidikan politik pada konteks ini seharusnya mengedepankan karakter dasarnya sebagai basic values, yakni; pertama, pendidikan tidak mendikotomikan antara ilmu umum (human science) dan ilmu-ilmu keagamaan ('ulüm al-dìn, theology science). Kedua, pendidikan Islam haruslah mempunyai karakter pendidikan yang berbasis pluralitas. Ketiga, pendidikan Islam haruslah menjadi lembaga pendidikan yang menghimpun dan menghidupkan sistem demokrasi dalam pendidikan.

Kalau kita menilik gagasan pendidikan politik humanistik yang membebaskan, kita bisa bercermin dari pemikiran demokratisasi yang digagas Freire. Sistem ini merupakan sistem pendidikan yang mengusung pendekatan dialog yang berusaha menempatkan subjek pendidikan (baik guru maupun murid) sebagi manusia yang memiliki jati diri masing-masing dan perlu berkembang secara bersama-sama. Selain itu Freire menawarkan pengajaran sistem pendidikan multikultural, dimana seluruh siswa diajari untuk 
senantiasa menghargai dan menghormati keanekaragaman atau kemajemukan yang terjadi di sekolah.27

Proses pengimplementasian antara gagasan Freire dan gagasan pemikir pendidikan politik terlihat dari gagasan sintesis-kreatif bagi pengembangan demokratisasi dan kesadaran. Wujudnya adalah; pertama, hakikat dan tujuan pendidikan sebagai proses untuk membina dan mengembangkan dan mengoptimalkan kompetensi manusia selaku hamba Allah sedangkan tujuannya adalah mewujudkan manusia sempurna yang dapat memenuhi kebutuhan materil dan spiritualnya. Kedua, konsep guru dan murid; guru sebagai pelaksana pendidikan yang menentukan, guru sebagai fasilitator, guru dan siswa sebagi subjek pendidikan yang sama-sama memiliki kemampuan untuk belajar bersama. Ketiga, metode pendidikan; metode pembelajran yang menyenangkan, mampu membangkitkan dan mengembangkan kompetensi siswa, sehingga siswa tidak hanya pintar membaca teks tapi juga pintar membaca konteks sosial remapt mereka hidup. Disinilah akan terbangun pendidikan politik yang Humanis

Dengan pemahaman keIslaman dan demokrasi yang lebih substantif ini masyarakat akan terhindar dari sikap beragama yang formalis-ritualis, sebab sikap demikian hanya akan menyempitkan makna beragama, orang tidak akan peka lagi terhadap realitas sosial yang dihadapi oleh masyarakat. Dalam konteks Islam, sebagai jawabnya adalah memahami Islam dengan corak kritis-humanis terhadap realitas yang ada di tengah masyarakat. Islam adalah keyakinan egaliter yang menolak perlakuan ketidakadilan karena alasan kelas, suku, ras, ideologi, agama dan gender. Dengan demikian nilai-nilai yang mendasari demokrasi dan liberalisme yang merupakan nilai-nilai universal yang harus diterima keberadaannya. ${ }^{28}$

Berangkat darai hal ini tokoh sperti Nurcholis Madjid, Abdurrahman Wahid dan Alwi Shihab menolak pemberlakuan syariat Islam sebagai hukum positif di Indonesia. Hal itu dikarenakan hukum Islam hendaknya dijadikan sebagai panduan moral yang dilakukan atas dasar kesadaran masyarakat yang mengikat dengan sendirinya, bahkan dipaksa oleh negara. Pengundangan hukum Islam haruslah sebatas apa yang diundangkan yaitu pada dataran yang berlaku pada semua komponen masyarakat, meskipun agamanya berbeda. ${ }^{29}$ Inilah yang disebut oleh Abdurrahman Wahid sebagai proses objektifikasi, yaitu proses pengakuan hukum secara objektif sebagai sesuatu yang diterima oleh masyarakat secara keseluruhan, meskipun hukum itu berasal dari agama lain yang sudah terinternalisasi. Disini tidak ada pengistimewaan terhadap kelompok agama tertentu, karena

\footnotetext{
${ }^{27}$ Abdullah Faisal Dkk, Metode dan Teknik KKN Participatorys Action Reseach, (P3M STAIN Surakarta dan LPTP Surakarta, 2007), hlm. 175

${ }^{28}$ Greg Barton, Biografi Gus Dur, hlm. xxx

${ }^{29}$ Abdurrahman Wahid, Prisma Pemikiran Gus Du, (Yogyakarta: LKiS, 2000), hlm. 32
} 
hukum agama yang telah diobjektifikasi telah menjadi milik bersama dan menjadi hukum publik (public law).

Paradigma pemikiran kalangan Islam humanis demikian tersebut pada dasarnya terbangun pada dua pendekatan, yaitu: pertama, pendekatan antropologi-kultural. Dalam pendekatan ini memungkinkan adanya integrasi kultural (cultural integration) yang merupaka gejala saling menyesuaikan antar unsur-unsur kebudayaan. Pendekatan ini kebanyakan digunakan oleh antropolog sebagai kerangka teoritis untuk menganalisis kebudayaan dan menerangkan cara-cara yang ditempuh oleh anggota masyarakat dalam menerima, menolak atau memodifikasi item-item yang berdifusi dengan kultur lainnya. Terdapat tarik menarik antara pola-pola ideal (ideal patterns) dan pola-pola real (real patterns). Pola-pola ideal mendefiniskan harapan-harapan normatif sedangkan pola-pola real mencakup berbagai variasi respon aktual individual.

Kedua, pendekatan historis-normatif (normative-history). Pendekatan normatif melibatkan komitmen keagamaan, dengan tujuan untuk mencari kebenaran agama dan tak jarang memfalsifikasi agama lain dan mengajak pemeluknya untuk pindah ke agama peneliti. Sedangkan pendekatan deskriptif berusaha untuk memahami agama-agama tanpa melibatkan komitmen peneliti terhadap kebenaran agama. Pendekatan ini bisa diperkaya dengan berbagai kajian seperti sosiologi, antropologi, psikologi dan sejarah.

\section{Orientasi Pendidikan Politik}

\section{a. Pendidikan Kesetaraan dan Berkeadilan}

Dalam pendidikan politik, demokrasi merupakan suatu proses karena demokrasi tidak dipandang sebagai suatu sistem yang sudah final dan sempurna. Karena itu, dengan sifatnya yang belum selesai maka akan selalu timbul reaksi sebagai alasan apologia bagi sistem yang ada. ${ }^{30}$ Demokrasi sebagai proses juga mengandung makna bukan hanya sekedar pelaksanaan konkret dari prinsip-prinsip demokrasi yang ada dan itu menjadi ukuran yang penting, karena dalam sistem ketatanegaraan, bahwa susunan kekuasaan yang secara formal sama, bisa didapat dari keadaan demokrasi yang berlainan.

Keadaan suatu demokrasi selalu mengalami perubahan sesuai dengan perkembangan sosial politik suatu negara dan tergantung dari imbangan kekuatan yang berlaku. Dengan pemahaman yang demikian memicu kita untuk mengumpulkan kekuatan yang banyak yang berpihak kepada demokrasi. Pendidikan politik mengindikasikan demokrasi sebagai alternatif bagi pengembangan sistem nilai dalam berbagai lapangan kehidupan manusia baik dalam kehidupan keluarga, masyarakat maupun

30 Greg Barton, Gagasan Islam Liberal di Indonesia. Pemikiran Neo-Modernis Nurcholish Madjid, Djohan Effendi, Ahmad Wahib dan Abdurrahman Wahid, (Jakarta: Paramadina, 1998), hlm. 427 
negara. Hal ini dikarenakan hampir semua negara di dunia ini menjadikan demokrasi sebagai asas yang fundamental dan esensial, yang secara paradigmatik telah memberikan arah bagi peranan masyarakat untuk menyelenggarakan negara sebagai organisasi tertinggi. Selain itu, demokrasi tidak saja merupakan bentuk final dan terbaik dari sebuah sistem negara, tetapi demokrasi dipahami sebagai dogma pemikiran politik yang luhur yang akan memberikan nilai guna yang lebih terhadap kelangsungan penyelengaraan negara.

Perlu sekiranya pendidikan politik menempatkan demokrasi sebagai dasar hidup bernegara, yang memposisikan masyarakat atau rakyat sebagai pemegang kekuasaan, pembuat, penentu keputusan, kebijakan serta pelaksaannya selalu berada di bawah kontrol masyarakat. Karena itu, negara yang demokratis mengindikasikan apabila dalam mekanisme pemerintahnya mewujudkan prinsip-prinsip dan nilai-nilai demokrasi, baik itu persamaan, kebebasan dan pluralisme.

Dalam kehidupan sosial yang plural, nilai-nilai demokrasi ada yang bersifat pokok dan ada yang merupakan nilai derivasi dari nilai pokok tersebut. Karena itu ada tiga nilai pokok dalam demokrasi, yaitu: kebebasan (liberty), keadilan (justice) dan musyawarah (syura). ${ }^{31}$ Kebebasan dalam konteks ini merupakan bentuk kebebasan individu dihadapan kekuasaan negara atau hak-hak individu warga negara dan hak kolektif dari masyarakat. Keadilan merupakan salah satu landasan demokrasi, dalam pengertian terbukanya peluang kepada semua orang dan juga ekonomi atau kemandirian dari orang yang bersangkutan untuk mengatur hidupnya sesuai dengan apa yang ia ingini. Keadilan menjadi nilai penting karena berkaitan dengan seseorang mempunyai hak menentukan jalan hidupnya, tetapi orang tersebut harus dihormati haknya dan diberi peluang serta kemudahan untuk mencapainya. Keadilan akan terwujud ketika orang tidak melihat halangan untuk mengekspresikan cita-cita dan keinginannya. Sedangkan syura' (musyawarah), merupakan bentuk atau cara memlihara kebebasan dan memperjuangkan keadilan tersebut lewat jalur permusyawaratan. ${ }^{32}$

Dalam konsep pendidikan politik berbasis pemikiran Islam humanis, paham demokrasi dan misi agama mempunyai kesamaan yang kuat, mengingat agama mempunyai kepentingan untuk menegakkan keadilan bagi kesejahteraan rakyat. Karenanya, agama dapat berjalan seiring dengan demokrasi selama ia melakukan transformasi bagi dirinya, secara intern maupun ekstern. Karena itu, untuk dapat melakukan transformasi intern itu agama harus merumuskan kembali pandangan-pandangannya mengenai martabat manusia, kesejajaran kedudukan semua manusia di muka undang-undang dan

31 Ahmad Amir Aziz, Neo-Modernisme Islam di Indonesia. Gagasan Sentral Nurcholish Madjid dan Abdurrahman Wahid, (Jakarta: Rineka Cipta, 1999), hlm. 65

32 Lihat Abdurrahman Wahid, "Sosialisasi Nilai-nilai Demokrasi", dalam M. Masyhur Amin dan Moh. Najib (ed.), Agama Demokrasi Dan Transformasi Sosial (Yogyakarta: LKPSM, 1993), hlm. 90 
solidaritas hakiki antar sesama umat manusia. 33 Pendidikan politik Islam dalam melakukan elaborasi pemikiran ditujukan untuk pengaplikasian demokrasi, bahwa suatu negara dapat dikatakan demokartis selama ia mampu menjamin hak-hak dasar asasi manusia, yaitu: jaminan keselamatan fisik, jaminan keselamatan keyakinan agama, jaminan kehidupan keutuhan rumah tangga, jaminan keselamatan hak milik, dan jaminan keselamatan akal. $^{34}$

Umat Islam Indonesia harus mewarisi semangat pluralisme yang tinggi, dengan menunjukan sikap positip terhadap pluralisme adalah suatu keharusan, tetapi terlebih karena tuntutan objektif dari realitas kehidupan modern. Pendidikan politik dalam Islam hendaknya melihat hubungan antara Islam dan pluralisme dalam konteks manifestasi universalisme dan kosmopolitanisme ajaran Islam, mengingat Islam menjamin lima hak dasar kemanusiaan, yaitu; keselamatan fisik warga masyarakat dari tindakan di luar hukum, keselamatan keyakinan agama tanpa paksaan, keselamatan keluarga dan keturunan, keselamatan harta benda dan milik pribadi, serta keselamatan profesi. ${ }^{35}$

Disisi yang lain, pendidikan politik juga banyak menyoroti pluralisme dalam tinjauan sosiologis. Berdasarkan kondisi demokrasi di Indonesia, ia melihat bahwa demokratisasi, toleransi dan kerukunan hidup beragama berjalan cukup baik, karena Islam masuk dengan corak yang lebih akomodatif terhadap budaya lokal, termasuk kepercayankepercayaannya sehingga terjadi akluturasi budaya yang kompleks. ${ }^{36}$ Tradisi kerukunan hidup beragama di Indonesia telah menjadi bangunan politik yang stabil dan mantap yang ditandai dengan adanya interaksi sosial yang harmonis antar pemeluk agama. Meskipun demikian, ia menilai bahwa watak normatif Islam jelas-jelas kosmopolitanis didukung sejumlah pengalaman sejarah, tetapi hal tersebut tidaklah berjalan mulus. Dalam konteks pembangunan toleransi beragama, belakangan ini umat Islam Indonesia mengalami suatu gejala yang dikenal dengan proses pendangkalan agama. ${ }^{37}$

33 Abdurrahman Wahid, "Agama dan Demokrasi", dalam YB. Mngunwijaya, dkk., Spiritualitas Baru: Agama dan Aspirasi Rakyat (Yogyakarta: Dian/Interfedei, 1994), hlm. 273

${ }^{34}$ Abdurrahman Wahid, "Sosialisasi Nilai-nilai Demokrasi", hlm. 97-98

35 Lihat Abdurrahman Wahid, "Universalisme Islam dan Kosmopolitanisme", dalam Budhy MunawarRahman, Kontekstualisasi Doktrin Islam dalam Sejarah (Jakarta: Paramadina, 1995), hlm. 546

36 Abdurrahman Wahid, "Hubungan Antar Agama-agama Dimensi Internal dan Eksternal di Indonesia", dalam Abdurrahman Wahid, dkk, Dialog Kritik dan identitas Agama, (Yogyakarta: Dian/interfidai, 1992), hlm. 6

37 Bagi Abdurrahman Wahid, proses pendangkalan agama ini disebabkan oleh beberapa hal, antara lain: pertama, pengaruh politik Islam yang menempatkan Islam sebagai ideologi, komuditas politik, baik yang menindas maupun yang tertindas. Kedua, faktor proses pendidikan dan dakwah yang cenderung bersifat memusuhi, mencurigai dan tidak mau mengerti agama lain. Faktor ini didorong oleh beberapa aspek, yaitu: pertama, mereka sedang mengalami masa transisi kehidupan dari tradisional ke modern, yang menyebabkan hilangnya akar-akar psikologis dan kultural. Kedua, Islam dijadikan ajang kepentingan politik yang dipakai untuk menghadapi orang lain. Abdurrahman Wahid, "Dialog Agama dan Masalah Pendangkalan Agama", dan "Kebebasan Agama dan Hegemoni Negara", dalam Komaruddin Hidayat dan Ahmad Gaus AF (ed.), Passing Over Melintasi Batas Agama (Jakarta: Paramadina, 1998), hlm. 51-52. 
Pada dasarnya demokrasi bukan hanya menyangkut sistem politik pada tingkat negara, dan lebih dari itu bahwa demokrasi juga mencakup kehidupan keseharian masyarakat. Proses demokrasi harus tercermin dalam interaksi antar kelompok dan golongan dalam masyarakat, karena pola kehidupan keluarga, bahkan hubungan antar individu harus didasarkan pada sistem demokrasi. Dalam pengertian lain bahwa demokratisasi harus dimulai dari ruang terkecil dalam interaksi masyarakat, baik pada tataran individu, struktur relasi kekuasaan juga menentukan esensi dan kualitas demokrasi level di atasnya yaitu masyarakat dan negara. ${ }^{38}$ Proses demokrasi akan berlangsung lebih baik jika setiap individu memiliki pengetahuan yang memadai tentang nilai-nilai demokrasi. Kedua tataran inilah yang menentukan karakteristik demokrasi modern yang oleh Huntington disebut sebagai demokrasi yang mendasarkan pada negara-kebangsaan. Ia mencita-citakan terciptanya tatanan masyarakat dunia yang dapat saling berdiri sejajar tanpa harus terdistorsi oleh ruang-ruang kesukuan maupun keagamaan.

Agama menurutnya akan dapat selaras dengan demokrasi jika memiliki watak membebaskan. Islam hadir ke dunia untuk membebaskan manusia dari belenggu keterbelakangan, mengingat Islam memberi kebebasan kepada umatnya untuk berkreasi menciptakan peradaban yang lebih manusiawi. Agama apapun sama-sama mengemban misi perbaikan kehidupan umat manusia melalui perubahan struktur masyarakat. ${ }^{39}$

Dengan tegas al-Qur'an menegaskan bahwa Muhammad diutus ke muka bumi untuk memberi rahmat bagi seluruh alam. Membangun kesejahteraan semesta, bukan menindas bangsa-bangsa. Titik temu antara agama dan demokrasi inilah yang menurut Abdurrahman Wahid harus dikedepankan dalam membangan Indonesia masa mendatang. potensi nalar agama akan sanggup menopang perjuangan penegakan demokrasi di Nusantara. Sehingga pada gilirannya proses demokratisasi tidak akan kehilangan ruh ketuhanannya. Tidak terjebak dalam budaya menyimpang semacam hedonisme dan matrealisme. Semua tentu menyadari bahwa tidak mudah mewujudkan demokrasi. Jack Snyder menggambarkan bahwa satu kekuatiran atas gagalnya proses demokratisasi dengan terjadinya conflict nationalist (konflik nasionalis), karena itu ia menawarkan resep yang menurutnya mampu menenggang perbedaan dan mengendorkan ketegangan antar kelompok yang saling berebut kekuasaan dalam suatu wadah demokrasi. ${ }^{40}$

38 Abdurrahman Wahid, Mengurai Hubungan Negara dan Demokrasi, (Jakarta: Grasindo, 1999), hlm. 30

${ }^{39}$ Ahmad Amir Aziz, Neo-Modernisme Islam di Indonesia, hlm. 58.

40 Airlangga Pribadi, "Memperjuangkan Pluralisme: Menata Peta-Jalan Arsitektur Masyarakat Pluralis", dalam Abd. Hakim dan Yudi Latif (Peny.), Bayang-bayang Fanatism: Esai-esai untuk Mengenang Nurcholish Madjid, (Jakarta: PSIK, 2007), hlm. 371. 


\section{b. Membangun Islam Transformatif}

Persoalan pembangunan demokrasi yang lebih substantif di atas harus dicarikan relevansinya dengan orientasi Islam yang ada saat ini. Tanpa pencarian yang serius maka tetap akan mendatangkan silang pendapat dan kekerasan akan terus terjadi. Untuk mencapai semua harus ada keberanian untuk melepaskan paham keagamaan kita dari muatan-muatan kepentingan politik sesaat, sebab segala kepentingan politik hanya akan mereduksi semangat kenabian yang bawa oleh agama. Al-Qur'an sebagai wahyu telah menjadi sumber kehidupan umat Islam apapun madzabnya, haruslah dipahami dalam kerangka yang lebih luas daripada sekedar bunyi teks al-Qur'an itu sendiri. Untuk sampai pada wilayah tersebut perlu dikaitkan dengan berbagai hal, termasuk dengan kehidupan nabi, kearifan para ulama, kebijakan filosof dan hal yang lainnya. Dengan demikian alQur'an akan menjadi nilai-nilai luhur yang merujuk pada kemaslahatan umat beragama. Dalam hal ini keadilan menjadi inti dari nilai kemaslahatan tersebut.

Mengutip pendapat Johan Efendi bahwa teologi yag dianut oleh umat Islam hendaknya tidak sekedar berkaitan dengan aspek kepercayaan pada Tuhan saja, akan tetapi juga harus berkaitan dengan hal-hal yang praksis dalam kehidupan keseharian umat manusia, lembaga-lembaga dan lingkungan. ${ }^{41}$ Menurut Khalid Abou El Fadl bahwa teks agama harus didekontruksi dengan mengajukan paradigma tafsir yang menekankan pada aspek etika dari pada aspek legal-formal. Tafsir keagamaan harus diselamatkan dari berbagai tafsir yang bisa mendorong otoritarianisme. Dalam kerangka membangun tafsir keagamaan yang bersifat otoritatif inilah Khalid Abou El-Fadl menekankan pada lima hal yaitu; pertama, kejujuran (honesty) dalam memandang mengungkapkan makna al-Qur'an tidak hanya dari aspek tekstual semata, namun juga melihat dari keseluruhan ajaran Tuhan melalui nabinya. Kedua, kesungguhan (deligence) dalam melakukan kajian tidak besifat subjektif, tetapi lebih menempatkan masalah secara komprehensif. Ketiga, kemenyeluruhan (comprehensive), melihat penafsiran dalam perspektif yang tunggal, melainkan beragama tafsir sebagai bentuk potensi yang akan mengarahkan pada tafsir fungsional dan transformatif. Keempat, kebijaksanaan dan kepantasan (reasonableness), rasional yang berdasarkan pada prinsipprinsip kepantasan umum. Kelima, pengendalian diri (self-restraint). Bagi Khaled berbagai penafsiran yang otoriter yang mengatasnamakan Tuhan hanya akan melahirkan fatwa keagamaan yang lemah akibat hilangnya ketelitian, kemenyeluruhan, dan kesungguhan dalam membedah sebuah persoalan.

Berangkat dari pemahaman yang demikian menurut penulis perlu memunculkan adanya penekanan pada aspek ahlak beragama (religious compassion) daripada fiqh (religious purification). Sehingga pengajaran agama pada masyarakat tidak selalu vertikal

41 Djohan Effendi,(ed.)., "Konsep-Konsep Teologis"dalam Budhi Munawarrahman", Kontekstualisasi Doktrin Islam dalam Sejarah, (Jakarta: Paramadina, 1994) hlm. 55 
akan tetapi juga pada ranah horizontal, lebih peka terhadap masalah-masalah yang berkembang di masyarakat. Masyarakat agama harus juga didorong untuk mengimplementasikan gagasan yang "melangit" pada kehidupan nyata. Misalanya gagasan menganai surga harus dibumikan pada kehidupan damai dalam masyarakat, penghormatan, pengorbanan, menyejahterakan kehidupan masyarakat.

Menurut Fazlurrahman perlu dikembangkan teologi transformatif dalam pemahaman tologi umat Islam. ${ }^{42}$ Tologi transformatif ini melihat aspek akidah sebagai bagian tidak terpisahkan dari ahlak yang kemudian diaktualisasikan dalam hukum yang harus ditaati dan dijalankan dalam setiap aspek kehidupan manusia. Teologi ini berpijak pada ajaran dan nilai moralitas agama yang holistik yang pada gilirannya meniscayakan untuk ditransformsaikan dan dikembangkan dalam ranah praksis. Teologi ini mencoba menghindarkan pemahaman umat Islam yang parsial, melepaskan beban sejarah keagamaan yang penuh pertentangan dan konflik yang sering kali mendistorsi nilai dan ajaran agama itu sendiri. Toelogi ini juga mencoba membangun proses keberagamaan yang kreatif dan penuh tanggung jawab untuk mengembangkan kehidupan yang selalu disandarkan pada nilai-nilai moralitas, keadilan, kesetaraan kedamaian dan kesejahteraan. Teologi ini mengandaikan adanya perbedaan tetapi sekaligus berkelindan antara agama yang memilki dimensi absolut dengan keberagamaan yang bersifat relatif. Keberagamaan hendaknya dilihat sebagai upaya manusia mendekati sesuatu yang absolut, meta-historis. Dengan demikian akan menghindarkan paham keagamaan yang one sided truth claim yang kaku dan sekaligus dapat mengambangkan keimanan yang kokoh yang dimanisfestasikan dalam bentuk sikap dan prilaku yang civilized sebagai cerminan ajaran agama. Pada gilirannya sikap demikian akan menghindarkan penganut agama dari tindakan kekerasan, perselisihan baik berbentuk individu atau antar lembaga keagamaan.

Alwi Shihab menunjukkan dua komitmen penting yang harus dipegang oleh umat beragama di Indonesia dalam beragama yaitu adanya sikap toleransi dan sikap pluralisme. Toleransi menurut Alwi adalah upaya untuk menahan diri agar potensi konflik dapat ditekan. Adapun yang dimaksud dengan pluralisme adalah tidak semata menunjuk pada kenyataan tentang adanya kemajemukan, namun adanya keterlibatan aktif terhadap kenyataan kemajemukan tersebut. ${ }^{43}$ Nurcholish Madjid juga mengungkapkan bagaimana sikap keberagamaan yang benar yang bisa dilaksanakan oleh masyarakat Indonsia yang majemuk ini. Ia menegaskan bahwa sebaik-baik agama di sisi Allah ialah alhanïfyyah al-samhah, agama yang memiliki semangat kebenaran yang lapang dan

42 Fazlurrahman, "Prinsip Syura dan Peran Umat Islam" dalam Mumtaz Ahmad (ed) Masalah Masalah Teori Politik Islam (Bandung, Mizan, 1994) hlm. 127. Juga Abdul 'ala, "Konflik Agama, Etnisitas dan Politik Kekuasaan" dalam Thoha Hamim, Resolusi konflik Islam Indonesia, (Surabaya: IAIN Surabaya Press, 2007), hlm. 114

${ }^{43}$ Alwi Shihab, Islam Inklusif: Menuju Sikap Terbuka dalam Beragama, (Bandung: Mizan, 1999) hlm. 41-43 
terbuka. Ia mengemukakan bahwa sikap mencari kebenaran secara tulus dan murni (haniffiyyah, kehanifan) adalah sikap keagamaan yang benar, yang menjanjikan kebahagiaan sejati, dan yang tidak bersifat palliative atau menghibur secara semu dan palsu seperti halnya kultus dan fundamentalisme. Maka Nabi pun menegaskan bahwa sebaikbaik agama di sisi Allah ialah al-haniffyyah al-samhah yaitu semangat mencari kebenaran yang lapang, toleran, tidak sempit, tanpa kefanatikan, dan tidak membelenggu jiwa. Disinilah pemahaman Nurcholis telah melampaui sekat-sekat doktriner agama, dimana ia meletakan kemanusiaan pada sisi yang paling tinggi dalam kehidupan beragama.

Disinilah kekerasan-kekerasan maupun kerusuhan sosial yang membawa identitas agama sudah semestinya dihentikan, jika tidak ingin memperpanjang sejarah permusuhan. Klaim terhadap adanya kekuasaan otoritas penafsiran sebuah teks bukan jalan terbaik untuk menciptakan pluralitas. Melakukan klaim atas sebuah pesan Tuhan sama artinya dengan memposisikan diri sebagai penjaga otoritas, dimana orang lain tidak berhak melewati apalagi memasukinya. Jadilah agama dipenuhi dengan sejulah rambu larangan yang justru menyulitkan bagi pemeluknya.

\section{Penutup}

Dari pembahasan di atas dapat disimpulkan; pertama, kalangan Islam humanis berpandangan bahwa nilai-nilai moral yang dibawa al-Qur'an secara substansialis telah memberikan panduan yang jelas bagaimana kehidupan manusia dibangun berdasarkan nilai-nilai keadilan dan kesamaan. Tujuan utama al-Qur'an tersebut adalah memberikan panduan berupa nilai-nilai dan perintah-perintah etik sosial kemasyarakatan dijunjung tinggi dan bersifat mengikat dalam kegiatan-kegiatan sosio-politik umat manusia. Karena itu, keharusan menegakan nilai-nilai etik-moral dari al-Qur'an menjadi keharusan bagi umat Islam, kapan dan dimanapun berada dengan cara yang positif-konstruktif. Pada titik inilah letak ruang gerak dari penafsiran-pemahaman yang harus selalu dikontekstualisasikan dengan perkembangan kontemporer.

Kedua, pendidikan politik berbasis ppemikiran Islam humaniter didasarkan pada nilai-nilai humanisme yang merupakan hakikat manusia. Materi pendidikan politik ini harus diupayakan untuk membangun kesadaran manusia secara mendasar. Adapun orientasi dari pendidikan politik ini adalah dalam rangka membangun kesadaran akan kesederajatan dan membangun islam substantif.] 


\section{DAFTAR PUSTAKA}

Abdullah, Amin, "Kesadaran Multikultural, dalam pengantar M. Ainul Yaqin, Pendidikan Multikultural: Cross Cultural Understanding untuk Demokrasi dan Keadilan, Jogjakarta: Pilar Media, 2005.

Studi Agama: Normativitas dan Historisitas, Yogyakarta: Pustaka Pelajar, 1999.

'Ala, Abdul, "Konflik Agama, Etnisitas dan Politik Kekuasaan" dalam Thoha Hamim, Resolusi konflik Islam Indonesia, Surabaya: IAIN Surabaya Press, 2007.

Aziz, Ahmad Amir, Neo-Modernisme Islam di Indonesia. Gagasan Sentral Nurcholish Madjid dan Abdurrahman Wahid, Jakarta: Rineka Cipta, 1999.

Azra, Azumardi, Pendidikan Islam Tradisi dan Modernisasi Menuju Melinium Baru, Jakarta: Logos, 2000.

Barton, Greg, Gagasan Islam Liberal di Indonesia. Pemikiran Neo-Modernis Nurcholish Madjid, Djohan Effendi, Ahmad Wahib dan Abdurrahman Wahid, Jakarta: Paramadina, 1998.

Chudlori, KH. Abdurrahman, Dasar Politik Kyai dan PKNU, Jakarta: DPP PKNU, 2007.

Effendi, Djohan, "Konsep-konsep Teologis"dalam Budhi Munawarrahman (ed), Kontekstualisasi Doktrin Islam dalam Sejarah, Jakarta: Paramadina, 1994.

Eposito, John L. dan John O. Voll, Demokrasi di Negara-negara Muslim: Problem dan Prospek, terj. Rahman Astuti, Bandung: Mizan, 1999.

Esaac, Farid, Al-Qur'an Liberation and Pluraisme: Membebaskan yang Tertindas, Bandung: Mizan, 2000.

Faisal, Abdullah, dkk, Metode dan Teknik KKN Participatorys Action Reseach, P3M STAIN Surakarta dan LPTP Surakarta, 2007.

Fazlurrahman, "Prinsip Syura dan Peran Umat Islam" dalam Mumtaz Ahmad (ed) Masalah Masalah Teori Politik Islam, Bandung: Mizan, 1994.

Hidayat, Komaruddin, "Tiga Model Hubungan Agama dan Demokrasi", dalam Elza Peldi Taher, Demokratisasi Politik Budaya dan Ekonomi, Jakarta: Paramadina, 1994.

Ismail, Faisal, Paradigma Kebudayaan Islam Studi Kritis dan Refleksi Historis, Yogyakarta: Tiara Illahi Press, 1998.

Jalal, Fasli, Reformasi Pendidikan dalam Konteks Otonomi Daerah, Yogyakarta: Aditia, 2001. MD, Mahfud, Hukum dan Pilar-pilar Demokrasi, Yogyakarta: Gama Media, 1999. 
Noer, Kautsar Azhari, “Tuhan Yang Diciptakan dan Tuhan Yang Sebenarnya”, Jurnal Paramadina, Vol I, Juli-Desember 1998.

Parekh, Bhikhu, "National Culture and Multiculturalism” dalam Kenneth Thomson (ed.), Media And Cultural Regulation, London: sage Publications. 1997.

Pribadi, Airlangga, "Memperjuangkan Pluralisme: Menata Peta-Jalan Arsitektur Masyarakat Pluralis", dalam Abd. Hakim dan Yudi Latif (Peny.), Bayang-bayang Fanatisme, Esai-esai untuk Mengenang Nurcholish Madjid, Jakarta: PSIK, 2007.

Shihab, Alwi, Islam Inklusif: Menuju Sikap Terbuka dalam Beragama, Bandung: Mizan, 1999.

Suaidy, Ahmad, Pesantren dan Demokratisasi, Yogyakarta: LKiS, 2000.

Suseno, Franz Magnis, 12 Tokoh Etika Abad ke-20, Yogyakarta: Kanisius, 2000.

Wahid, Marzuki (ed), Jejak Jejak Islam Politik, Synopsis Sejumlah Studi Islam Indonesia Jakarta: Dirjen Diktis Kemenag RI, 2004.

Wahid, Abdurrahman, "Agama dan Demokrasi", dalam YB. Mngunwijaya, dkk., Spiritualitas Baru: Agama dan Aspirasi Rakyat, Yogyakarta: Dian Interfedei, 1994.

, “Dialog Agama dan Masalah Pendangkalan Agama”, dan "Kebebasan Agama dan Hegemoni Negara", dalam Komaruddin Hidayat dan Ahmad Gaus AF (ed.), Passing Over Melintasi Batas Agama, Jakarta: Paramadina, 1998.

, "Dialog Agama dan Masalah Pendangkalan Agama", dan "Kebebasan Agama dan Hegemoni Negara", dalam Komaruddin Hidayat dan Ahmad Gaus AF (ed.), Passing Over Melintasi Batas Agama, Jakarta: Paramadina, 1998.

, "Hubungan Antar Agama-Agama Dimensi Internal dan Eksternal di Indonesia", dalam Abdurrahman Wahid, dkk., Dialog Kritik dan identitas Agama, Yogyakarta: Dian Interfidai, 1992.

,Islam dan Masyarakat Bangsa”, Jurnal Pesantren, Jakarta, Vol. VI, No. 3, 1989, , “Islam Punyakah Konsep Kenegaraan?” Tempo, 26 Maret 1982.

, "Kata Pengantar", dalam Einar Martahan Sitompul, Nahdaltul Ulama dan Pancasila, Jakarta: Sinar Harapan, 1989.

, "Sosialisasi Nilai-Nilai Demokrasi", dalam M. Masyhur Amin dan Moh. Najib (ed.), Agama Demokrasi dan Transformasi Sosial Yogyakarta: LKPSM, 1993.

, "Universalisme Islam dan Kosmopolitanisme Peradaban Islam", dalam Budhi Munawar Rahman (ed.), Kontekstualisasi Doktrin Islam dalam Sejarah, Jakarta: Paramadina, 1994.

"Universalisme Islam dan Kosmopolitanisme", dalam Budhy Munawar-Rahman, Kontekstualisasi Doktrin Islam dalam Sejarah, Jakarta: Paramadina, 1995. 
_. Mengurai Hubungan Negara dan Demokrasi, Jakarta: Grasindo, 1999.

_ Prisma Pemikiran Gus Dur, Yogyakarta: LKiS, 2000. , Tuhan Tak Perlu Dibela, Yogyakarta: LKiS, 1999.

Yaqin, M. Ainul, Pendidikan Multikultural: Cross Cultural Understanding untuk Demokrasi dan Keadilan, Jogjakarta, Pilar Media, 2005.

Zada, Khamami (ed.), Neraca Gus Dur di Panggung Kekuasaan, Jakarta: Lakspedam, 2002. 